\title{
Performance of biofilm carriers in anaerobic digestion of sisal leaf waste leachate
}

\author{
Anthony Manoni Mshandete* \\ Department of Molecular Biology and Biotechnology \\ University of Dar es Salaam \\ P.O. Box 35179 Dar es Salaam, Tanzania \\ Tel: 255224110223 \\ Fax: 255222410078 \\ E-mail: mshandete@amu.udsm.ac.tz \\ Lovisa Björnsson \\ Department of Biotechnology \\ Centre for Chemistry and Chemical Engineering \\ Lund University \\ P.O. Box 124, SE-22100, Lund, Sweden \\ Tel: 46462228324 \\ Fax: 46462224713 \\ E-mail: lovisa.bjornsson@biotek.lu.se

\section{Amelia Kajumulo Kivaisi} \\ Department of Molecular Biology and Biotechnology \\ University of Dar es Salaam \\ P.O. Box 35179 Dar es Salaam, Tanzania \\ Tel: 255224110223 \\ Fax: 255222410078 \\ E-mail: akivaisi@amu.udsm.ac.tz
}

\section{Mugassa Steven Thomas Rubindamayugi \\ Department of Molecular Biology and Biotechnology \\ University of Dar es Salaam \\ P.O. Box 35179 Dar es Salaam, Tanzania \\ Tel: 255224110223 \\ Fax: 255222410078 \\ E-mail: mugassa@amu.udsm.ac.tz \\ Bo Mattiasson \\ Department of Biotechnology \\ Centre for Chemistry and Chemical Engineering \\ Lund University \\ P.O. Box 124, SE-22100, Lund, Sweden \\ Tel: 46462228264 \\ Fax: 46462224713 \\ E-mail: bo.mattiasson@biotek.lu.se}

Financial support: The Swedish International Development Cooperation Agency (SIDA) and the Swedish Agency for Research Cooperation (SAREC), project SWE 2003-021.

Keywords: biogas, methanogenesis, packed-bed bioreactors, packing media.

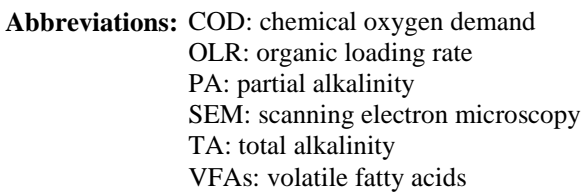

Three methanogenic biofilm bioreactors were studied to evaluate the performance of three types of carriers. The carrier material were consisted of sisal fibre waste, pumice stone and porous glass beads, and the bioprocess evaluated was the methanogenesis anaerobic digestion of sisal leaf waste leachate. Process performance was investigated by increasing the organic loading rate (OLR) step-wise. The best results were

*Corresponding author 
obtained from the bioreactor packed with sisal fibre waste. It had the highest chemical oxygen demand (COD) removal efficiencies in the range of $80-93 \%$ at OLRs in the range of 2.4-25 g COD $\mathrm{L}^{-1} \mathrm{~d}^{-1}$. The degradation pattern of volatile fatty acids (VFAs) showed that the degradation of propionate was limiting at higher OLRs. The stable $\mathrm{pH}$ and higher partial alkalinity (PA) of the outflow illustrated that packedbed bioreactors have a good ability to withstand the variations in load and volatile fatty acid concentrations that can occur in a two-stage anaerobic process. In conclusion, sisal fibre waste was shown to be a novel promising biofilm carrier and would work very well in methanogenic biofilm bioreactors treating sisal leaf tissue waste leachate. Furthermore both sisal wastes are available in the neighbourhood of sisal industries, which makes anaerobic digestion scale up at sisal factory level feasible and cost-effective.

The application of modern biogas technology for the utilization of abundantly available biomass residues generated by agro-based and food processing industries, and municipalities has a potential to generate biogas fuel which can be used to replace petroleum fuels or be converted to electricity. Processing of the sisal plant (genus Agave) which ranks $6^{\text {th }}$ place among fibre plants, is one of the industries with high potential. It is a high waste generating industry with a current ratio of useful fibre to waste at 2:98\%. In Tanzania the current estimated annual productions of sisal leaf, sisal fibre and sisal stem wastes are 440,000; 148,000; and 1,000,000 tons, respectively. Current disposal methods of these residues include burning, and dumping on site or dumping in unplanned and uncontrolled landfills, or discharging in nearby rivers/streams causing serious environmental problems. Exploitation of the residues generated by the sisal industry for alternative energy source is however constrained by lack of knowledge on the appropriate bioconversion technologies as well as the linear production system for sisal plants which makes the sisal industry interested in the sisal fibres and not in the other products. A holist approach to the utilization of sisal plant and extraction of all residues the plant is generating will make the sisal industry sustainable, profitable and competitive. Research efforts to address this view are being made. Recent laboratory investigations have shown that the anaerobic digestion of sisal leaf tissue and sisal fibres residues is technically feasible (Mshandete et al. 2004; Björnsson et al. 2005; Mshandete et al. 2005; Mshandete et al. 2006). Furthermore, a project for production of biogas, electricity and bio-fertilizer from sisal waste at pilot scale in Tanzania has been proposed.The US\$ 5.3 million project is cofinanced by United Nations Industrial Development Organization (UNIDO), the Common Fund for Commodities (CFC), the International Fund for
Agricultural Development (IFAD), the Belgian Government and counterpart contributions from Tanzania and Kenya. This project provides an opportunity and a challenge for further research to improve on biogas production from sisal residues prior to full scale plants.

Anaerobic digestion systems are limited by two major steps depending on the nature of the substrates. Hydrolysis is often limited if the substrate is complex organic solids while in the digestion of soluble organic matter, the rate limiting step has been identified as methanogenesis. Since a major drawback in a bioreactor based on anaerobic digestion of soluble substrate is the slow growth rate of methanogens, the desirable degree of organic matter degradation is achieved after along residence time in the anaerobic reactor (Yang et al. 2004). Attempts are being made to overcome this problem in the today's high-rate reactors with effective biomass retention (Harendranath et al. 1996; Ince et al. 2000). To maintain high microbial cell densities in the anaerobic bioreactor, methods of immobilizing microbial cells on various supports/medium have been studied (Lalov et al. 2001; Held et al. 2002; Suvajittanont and Chaiprasert, 2003; Yang et al. 2004). Adhesive growth supports high cell density and thus high activity. However, adoption of immobilization technology by the developing countries requires the use of cheap and easily available biofilm carriers. The sisal fibres waste from Agaves species are extremely strong, rough, hard, durable fibre, and resistant to the effects of many chemical solutions and solvents, contains two steroidal saponinsyuccagenin and ruizgenin which can be used as natural chelating agents (Romero-González et al. 2006). These characteristics make sisal fibre waste a potential biomaterial for the microbial cell immobilization. Another locally available alternative in Tanzania is pumice, which is a volcanic material; porous in nature with a high surface area that could be useful for microbial immobilization. In this paper results of the evaluation of sisal fibre waste, pumice stone and porous glass beads as biofilm carriers in the methanogenic bioreactors treating sisal leaf tissue waste leachate are reported. To the best of our knowledge, results on performance of these materials as biofilm carriers for anaerobic digestion of sisal residues are being reported for the first time.

\section{MATERIALS AND METHODS}

\section{Biofilm carriers}

The sisal fibre waste was collected from a sisal-processing factory at Ubena Zomozi, Tanzania and was sun dried for 5 days and then stored at room temperature. The characteristics of sisal fibre waste are given in (Table 1). Pumice stones which are, light, siliceous, greyish-coloured volcanic rocks, with a size of 7-23 $\mathrm{mm}$ and high porosity (>95\%), were provided by the National Housing and Building 


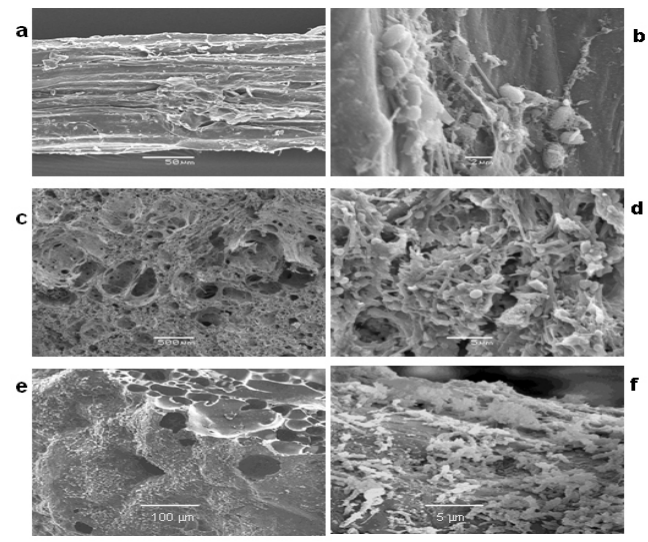

Figure 1. Scanning electronic micrographs of support materials: (a) sisal fibre waste (mag. x 500), (c) pumice stone (mag. $x$ 35) and (e) porous glass beads surface and cross section (mag. $x$ 150) before microbial colonisation, and after colonisation with anaerobic microbial biofilms: (b) sisal fibre waste (mag. x 6000), (d) pumice stone (mag. $x$ 3000) and (f) porous glass beads (mag. x 2300).

Research Unit, NHBRU (Dar es Salaam, Tanzania). Porous glass beads with a diameter of $15 \mathrm{~mm}$ and high porosity (>90\%) made from recycled glass were supplied by Dennert Poraver GmBH (Lauingen, Germany).

\section{Substrates and synthetic media}

The sisal leaf tissue waste was collected from a sisalprocessing factory at Ubena Zomozi, Tanzania and was stored at $-20^{\circ} \mathrm{C}$ until use. Prior to the preparation of the synthetic medium, an analysis of the effluent from the first stage reactor was made for volatile fatty acids (VFAs) and chemical oxygen demand (COD) which are the major components. This was on the basis of a previous study by Anderson and Björnsson (2002) which measured COD and all VFAs of an effluent of a first stage bioreactor fed with sisal leaf residues where it was seen that the COD was actually completely made up of VFAs. Hence even if other organics were there, their concentrations were very low and hence not likely to affect the degradation rates. Thus the characteristics of the effluent from the first stage bioreactor was used as a model substrate. However, in order to obtain reproducible conditions for the evaluation of the methanogenic step a synthetic substrate was used with a total influent VFAs concentration of $20.6 \mathrm{~g} \mathrm{~L}^{-1}$. The individual VFAs including propionate, n-butyrate and acetate were added at concentrations of 4.5, 4.9 and $8.9 \mathrm{~g} \mathrm{~L}^{-1}$, while for ivalerate, i-butyrate and n-valerate the concentrations were $0.4,0.7$ and $1.2 \mathrm{~g} \mathrm{~L}^{-1}$, respectively. The composition of other compounds/nutrients in the synthetic substrate was as reported by Andersson and Björnsson (2002).

\section{Bioreactor design}

The experimental set-up consisted of three methanogenic bioreactor configurations of identical size (volume $2 \mathrm{~L}$, height $420 \mathrm{~mm}$ and an internal diameter of $60 \mathrm{~mm}$ ). The bioreactors were operated under identical conditions but packed with different biofilm carriers, and were run in parallel. The sisal fibre waste was packed to a density of $145 \mathrm{~g} \mathrm{~L}^{-1}$. This is the packing density commonly used in baling commercial sisal fibre. The second bioreactor containing pumice stone was packed to a density of $271 \mathrm{~g}$ $\mathrm{L}^{-1}$, while the third bioreactor was packed with porous glass beads to a density of $174 \mathrm{~g} \mathrm{~L}^{-1}$. The study was carried out at mesophilic conditions $\left(35-37^{\circ} \mathrm{C}\right)$. All the packed-bed bioreactors had a constant upflow recirculation of $10 \mathrm{~mL}$ $\min ^{-1}$. In all the bioreactors, the substrate was pumped in at the bottom (upflow) of the bioreactors and the effluent and the biogas were discharged from the top through the same outlet. The liquid was then separated from the gas, which was collected in a gas-tight bag.

\section{Experimental procedure}

Each bioreactor was inoculated with $500 \mathrm{~mL}$ sludge from a mesophilic sewage sludge digester (Eslöv, Sweden). During the start-up period, the inoculum was continuously recirculated and $100 \mathrm{~mL}$ of leachate extracted during sisal fibre waste pre-digestion was fed to each bioreactor once every two weeks. A start-up period of five months was employed in order to establish the biofilms, and to degrade the biodegradable part of the sisal fibre waste, which would otherwise wrongly contribute to the methane production of that process. After the start-up period, the substrate was added and the three bioreactors were operated continuously for 70 days. In order to determine the maximum efficiency of each packed-bed bioreactor, the organic loading rate (OLR) was increased step-wise. Each process was evaluated by analyzing the volume and content of the gas, concentration of VFAs, COD, Partial Alkalinity (PA), Total Alkalinity (TA) and the $\mathrm{pH}$ of the outflows. OLRs in the range of 2.4-25 g COD L ${ }^{-1} \mathrm{~d}^{-1}$ were investigated, and each OLR was maintained for at least three retention times in order to attain a steady state.

\section{Scanning electron microscopy}

Microbial cell immobilization on carriers was visualized using scanning electron microscopy (SEM). The biofilm carriers before and after the experiment were scanned. The samples for SEM were fixed in 2.5\% glutaraldehyde in 0.15 $\mathrm{M}$ sodium cacodylate buffer at $\mathrm{pH} 7.2$, overnight. The samples were then post-fixed in $1 \%$ osmium tetroxide for 1 $\mathrm{hr}$, dehydrated in ethanol and then dried. Dried samples were coated with gold/palladium (40/60) to make them electrically conducting and to avoid space charge effects during SEM. The samples were examined at $10 \mathrm{kV}$ in secondary electron mode using a JOEL JSM-5600, scanning electron microscope (JOEL Ltd, Tokyo, Japan).

\section{Analytical methods}

The volume of biogas was measured using a wet-type precision gas meter (Schlumberger, Karlsruhe, Germany) and biogas composition was measured using gas 
chromatography, (Varian 3350, Walnut Creek, CA, USA) as previously reported by Björnssonet al. (1997). The PA, TA, pH, VFAs were measured as previously described (Andersson and Björnsson, 2002). Neutral detergent fibres (NDF, total fibre in the substrate), Acid detergent fibres (ADF, primarily comprises of cellulose and lignin of the substrate), cellulose and lignin (permanganate method) contents of the sisal leaf tissue and sisal fibre waste were analyzed in duplicate according to the method of Goering and Van Soest (1970). Total solids (TS), volatile solids (VS) and COD were determined according to standard methods APHA (1998).

\section{RESULTS AND DISCUSSION}

\section{Physical properties of biofilm carriers before and after microbial colonisation}

The size, shape, hydrophobicity, surface to volume ration of the matrix, surface charge, porosity and roughness of the carrier material are reported to influence bacterial colonization on the support media (Harendranath et al. 1996; Ødegaard et al. 2000). Moreover, the ability of the support material to entrap and prevent washout of biomass has been found to sometimes be a more important parameter than the surface area of the medium (Gikas and Livingston, 2006). The three biofilm carriers investigated had different porosities, sizes, shapes and surface areas, resulting in different capabilities of retaining biomass in the carrier. From the micrograph (Figure 1a) it can be seen that uncolonized sisal fibre waste has rough, uneven surface with crevices, microscopic ridges and pores which are good for attachment and entrapment of microbes, as can be seen in (Figure 1b). In studies of sisal fibres as reinforcement in polymers, microscopic observations have revealed that the presence of the rough surface of sisal fibres favoured biofilm growth, which is a strong advantage (di Franco et al. 2004). Furthermore, it has been shown in other studies that jute fibre which is similar to sisal fibres possesses natural chelating properties that make it a good adsorbent. These characteristics make sisal fibre waste a potential cheap bioresource for the microbial cell immobilization in anaerobic biotechnological applications (Banerjee and Dastidar, 2005). A micrograph of a pumice stone (Figure 1c) shows, a rough, high porous surface area with macrostructures variable in size and shape, which could allow organisms which adhere to the surface to be entrapped as seen in (Figure 1d). This could prevent washout. Although porous, the internal pores of the glass beads (Figure 1e) are not available for the attachment of biomass, and hence biofilm growth takes place mainly on the surface (Figure 1f). The microscope images in Figure 1a and Figure 1b do not clearly show that the surfaces of the sisal fibers are more suitable for biofilm attachment than the pumice. However, biomass within in an anaerobic filter grows in the form of both biofilm attached to the medium and suspended particles entrapped within the medium. It has been shown that in anaerobic filters, the organic removal contribution from entrapped suspended biomass is relatively significant (Alves et al. 1998; Agamuthu, 1999). Hence the amounts of suspended biomass retained by sisal fibre waste may have played an important role in the observed differences in process performance. The biodegradation of the sisal fibre was measured at the end of the experimental period, and although around 50\% of the sisal fibre waste was degraded during the experimental period of about 8 months no clogging or drainage problems were encountered. This finding is important and it illustrates that sisal fibre waste is a novel biofilm carrier which could be successfully applied in anaerobic biotechnology systems treating sisal leaf tissue waste leachate for long time without serious technical problems. Studies on characterizations and the effect of biofilm formed on the surface of the three carriers are underway.
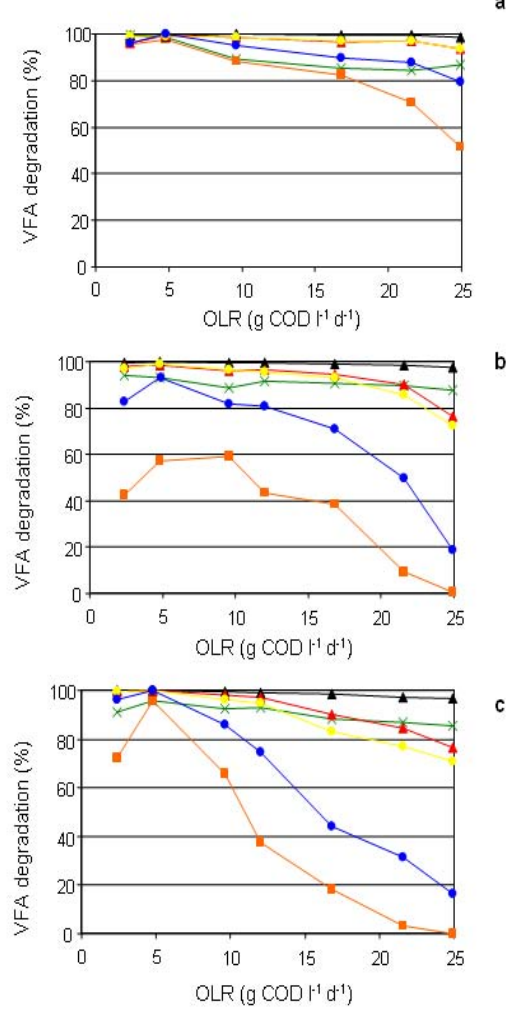

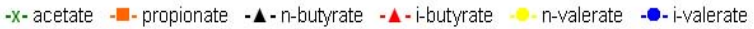

Figure 2. Percentage degradation of individual VFA with increasing OLR for sisal fibre waste (a) pumice stone (b) porous glass beads (c) packed-bed bioreactors.

\section{VFA degradation with increasing OLR}

VFAs are important intermediary compounds in the metabolic pathway of methane fermentation (Parawira et al. 2005). However, accumulation of VFAs and lowering of $\mathrm{pH}$ are known to lead to suppression of methanogenic activity and process failure in methanogenic, reactors. The results of individual VFA degradation with increasing OLR 
for the three packed-bed bioreactors are shown in (Figure 2 ). The VFA degradation rate was calculated from the mean values of the VFAs in the outflows for at least 3-6 days of operation at each OLR, and is given as percentage of individual VFA degraded. The amounts of VFAs in the outflow of methanogenic bioreactors may change significantly due to changes in the OLR. The results showed that the total outflows of VFAs and COD concentrations were fairly well correlated (Figure 3). However, the pattern of individual VFAs in the outflow varied between the bioreactors in response to the OLR applied. The percentage degradation of acetate, n-butyrate, i-butyrate and n-valerate in the three bioreactors shows some similarities, being degraded by over $70 \%$, even at an OLR of up to $24.9 \mathrm{~g} \mathrm{COD} \mathrm{L}^{-1} \mathrm{~d}^{-1}$. Normally, acetate and propionate are predominating VFAs found in the outflows of methanogenic bioreactors in case of reactor overloads. Thus the effects of acetate and propionate degradation are most important for judging the performance of the digester (Mösche and Jördening, 1999; Pullammanappallil et al. 2001). Acetate was added at high initial concentrations. In addition, acetate is also a product of degradation of VFAs with more than 4-C chains (Wang et al. 1999). In spite of the high concentration, acetate degradation was over $85 \%$ in all bioreactors even at the highest COD L-1 $\mathrm{d}^{-1}$ applied (24.9 g). This result implies that acetate was degraded into $\mathrm{CH}_{4}$ and $\mathrm{CO}_{2}$ by the methanogens, indicating that the overall process was not overloaded by acetate. However, the degradation efficiency of propionate in the three bioreactors decreased when the process was subjected to high OLRs. High propionate concentration in methanogenic bioreactors has been reported during changes in the process balance in response to high OLRs (Pind et al. 2002). For the bioreactors with pumice stones and glass beads packed beds, propionate degradation efficiency dropped drastically, and in some cases was even negative when the OLR was increased over $12 \mathrm{~g} \mathrm{COD} \mathrm{L}^{-1} \mathrm{~d}^{-1}$. However, the propionate degradation efficiency was still over $50 \%$ for the sisal fibre waste biofilm carrier, even when the OLR was increased to 24.9 g COD L $^{-1} \mathrm{~d}^{-1}$. According to previous studies raw sisal decortication residues contain relatively high concentration of total VFAs, in the range of 4-6 g/l, and propionic acid is at more than $1 \mathrm{~g} / \mathrm{l}$ (Rubindamayugi and Salakana, 1997). It is hence likely that the sisal fibre waste which was used as a biofilm carrier had an indigenous population of microorganisms adapted to converting propionic acid. It is hence most probable that this population increased and was maintained with the step wise feeding of the bioreactor with propionic acid. This view is in agreement with that of Pullammanappallil et al. (2001) who managed to maintain a population of propionate degrading microorganisms within a digester by feeding propionate at $1 \mathrm{~g} / \mathrm{l}$ with a medium composed of glucose and phenol. Furthermore the conversion of propionate has been reported to proceed through different pathways including 1) syntrophic conversion 2) reductive carboxylation and 3) conversion into higher fatty acids which are thermodynamically easily converted into methane. It is therefore likely that the indigenous population in the sisal fibre waste biofilm carrier consisted of microbes capable of carrying out one or all of the three pathways (Lens et al. 1996). The accumulation of propionate is caused by imbalance between the acetogenic bacteria, converting higher VFAs such as propionate and butyrate into acetate, carbon dioxide and hydrogen, and the hydrogenotrophic methanogens, which utilize $\mathrm{H}_{2}$ and $\mathrm{CO}_{2}$ to produce methane. Degradation of propionate it is inhibited under high hydrogen concentrations, thus a syntrophic association between the obligate hydrogen-producing acetogenic bacteria and the hydrogen-consuming methanogens is required for the degradation to proceed (Pind et al. 2002). An accumulation of VFAs will result in a decrease in $\mathrm{pH}$, and finally lead to failure of the methanogenic stage and the whole degradation process (Wang et al. 1999). The results presented by Andersson and Björnsson (2002) from similar treatment system showed a comparable decrease in propionate degradation rate as the OLR was increased. The degradation of i-valerate was distinctly different in the three bioreactors. It was low in the pumice stone and glass-bead packed-bed bioreactors when the OLR was increased over $12 \mathrm{~g} \mathrm{COD} \mathrm{L}^{-1} \mathrm{~d}^{-1}$. The effluent from these bioreactors at the highest OLR applied contained 0.325-0.355 $\mathrm{g} \mathrm{L}^{-1}$ compared to the influent of $0.400 \mathrm{~g} \mathrm{~L}^{-1}$. This demonstrates that the microbial activity in the bioreactors was inhibited at a high OLR. The most probable reason for better degradation efficiencies of i-valerate for sisal fibre waste packed-bed bioreactor compared to the pumice stone and glass-bead packed-bed bioreactors is that indigenous microorganisms capable of oxidizing i-valerate into acetate a natural methanogens substrate, were probably present in sisal fibre decortications wastes. The conversion of i-valerate to acetate has been suggested to proceed via beta-oxidation degradation pathways (Batstone et al. 2003). The microorganisms in sisal waste fibres carrier seem to be able to sustain much higher VFAs concentrations with increasing OLRs without concomitant serious operational problems. This shows that it could be a potential biofilm carrier to facilitate the retention of slow-growing organisms thereby stabilizing anaerobic digestion process in sisal wastes based bioreactors.
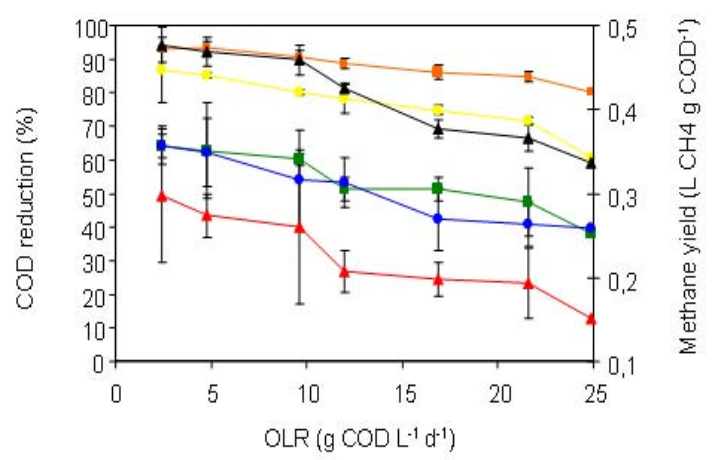

Figure 3. COD reduction $\%$ and methane yield methane per gram of added COD at increasing OLR for sisal fibre waste ( $I$ $\square)$, pumice stone ( I ) and porous glass bead ( $\Delta / \Delta)$ packedbed bioreactors. 


\section{COD reduction and methane yield}

The COD reduction is a measure of the treatment efficiency in anaerobic filters (Agamuthu, 1999; Ødegaard et al. 2000). Figure 3 shows the COD reduction and methane yield for each OLR in the three packed-bed bioreactors. The values are given as average values and standard deviations for 3-6 measurements over 3-6 days of operation at each OLR. Generally, there was a good correlation between COD reduction and methane yield, which shows how the treatment efficiency decreased with increasing OLR. Such observed tendencies and phenomenon are common in anaerobic treatment systems and have been reported by others (Ince et al. 2000). In this study the performance of the sisal fibre waste biofilm in methanogenic bioreactor was very good, showing a COD reduction of around $80 \%$ even at an OLR of $25 \mathrm{~g} \mathrm{COD} \mathrm{L}^{-1}$ $\mathrm{d}^{-1}$ and a hydraulic retention time of 24 hrs.

Biogas content, methane production rate, $\mathrm{pH}$ and alkalinity

The methane contents in all the three bioreactors varied between 82 and $86 \%$ and were very similar as the OLR was increased from 2.4 to $24.9 \mathrm{~g} \mathrm{COD} \mathrm{L}^{-1} \mathrm{~d}^{-1}$ (data not shown). The methane production rate (MPR) for the three bioreactors varied between 0.3 and $2.6 \mathrm{~L} \mathrm{CH}_{4} \mathrm{~L}^{-1} \mathrm{~d}^{-1}$ and increased with increasing OLR. The maximum methane production of $2.6 \mathrm{~L} \mathrm{~L}^{-1} \mathrm{~d}^{-1}$, was achieved in the sisal fibre waste packed-bed bioreactor at an OLR of $24.9 \mathrm{~g} \mathrm{COD} \mathrm{L}^{-1}$ $\mathrm{d}^{-1}$ (data not shown). Measuring alkalinity provides a picture of how safe the bioreactor is in relation to buffering acidic shock loadings. The PA outflow values were between 6.7-9.7 g CaCO3 L ${ }^{-1}$ (data not shown) and $\mathrm{pH}$ 8.18.3 (data not shown) in all the bioreactors during stable operation. The values obtained in this study for the outflow $\mathrm{PA}$ and $\mathrm{pH}$ are within data reported in the literature. A PA in the range of 1.0-5.0 g CaCO3 $\mathrm{L}^{-1}$ and $\mathrm{pH}$ 6.5-8.5 were reported for a normal and healthy operation of anaerobic digester (Mshandete et al. 2004; Mshandete et al. 2006). The inlet substrate $\mathrm{pH}$ was maintained at 5.6, and the neutralizing capacity of the packed-bed systems was good since the $\mathrm{pH}$ was stable without any need for $\mathrm{pH}$ control. This is an interesting cost-effective approach for anaerobic digestion of sisal residues in Tanzania since no eternal buffer sources was added.

\section{CONCLUDING REMARKS}

This is the first study reporting the utilization of sisal fibres waste, pumice and porous glass beads as a biofilm carrier in anaerobic digestion of sisal leaf tissue waste leachate. From the results obtained, we can conclude that the performance of the packed-bed bioreactor containing sisal fibre waste as a biofilm carrier was superior to those of the other bioreactors investigated and sisal fibre waste is an appropriate biofilm carrier to use in methanogenic bioreactors digesting sisal leaf tissue waste leachate. Higher COD removal and the degradation efficiency of individual
VFAs as well as an effluent with stable $\mathrm{pH}$ and high alkalinity were observed. Furthermore, a biofibre carrier as sisal fibre waste did not suffer from clogging or channelling even though some degradation occurred during the 8 months duration of this study. An additional benefit is that both sisal fibre and sisal leaf tissue are wastes produced in sisal factories, which makes scale-up at sisal factory level cost-effective in terms of handling and transport. However, further research is necessaryto evaluate the feasibility of pilot scale up and gain more understanding and improve the anaerobic digestion system in the context of Tanzania's low technology environment.

\section{ACKNOWLEDGMENTS}

We thank BIO-EARN (East African Regional Programme and Research Network for Biotechnology, Biosafety and Biotechnology Policy development) programme for including environmental biotechnology as one of the research theme in the programme. A.M.M. acknowledge remarkable stimulating environment for avenues of knowledge and inspiration from the environmental and biogas groups, Department of Biotechnology Lund University. We also thank Rita Wallèn Department of Cell and Organism Biology, Lund University for technical help during SEM.

\section{REFERENCES}

AGAMUTHU, P. Specific biogas production and role of packing medium in the treatment of rubber thread manufacturing industry wastewater. Bioprocess and Biosystems Engineering, August 1999, vol. 21, no. 2, p. 151-155.

ALVES, M.M.; PEREIRA, M.A.; BELLOUTI, M.; ALVARES PEREIRA, R.M.; MOTA VIEIRA, J.A.; NOVAIS, J. and MOTA, M. A new method to study interactions between biomass and packing material in anaerobic filters. Biotechnology Techniques, April 1998, vol. 12, no. 4, p. 277-283.

ANDERSSON, Jonatan and BJÖRNSSON, Lovisa. Evaluation of straw as a biofilm carrier in the methanogenic stage of two-stage anaerobic digestion of crop residues. Bioresource Technology, October 2002, vol. 85, no. 1, p. 51-56.

ANDERSSON, Jonatan and BJÖRNSSON, Lovisa. Evaluation of straw as a biofilm carrier in the methanogenic stage of two-stage anaerobic digestion of crop residues. Bioresource Technology, October 2002, vol. 85, no. 1, p. 51-56.

BANERJEE, S. and DASTIDAR, M.G. Use of jute processing wastes for treatment of wastewater contaminated with dye and other organics. Bioresource Technology, November 2005, vol. 96, no. 17, p. 1919-1928. 
BATSTONE, D.J.; PIND, P.F. and ANGELIDAKI, I. Kinetics of thermophilic, anaerobic oxidation of straight and branched chain butyrate and valerate. Biotechnology and Bioengineering, 2003, vol. 84, no. 2, p. 195-204.

BJÖRNSSON, L.; MATTIASSON, B. and HENRYSSON, T. Effects of support material on the pattern of volatile fatty acid accumulation at overload in anaerobic digestion of semi-solid waste. Applied Microbiology and Biotechnology, June 1997, vol. 47, no. 6, p. 640-644.

BJÖRNSSON, L.; MSHANDETE, A. and MATTIASSON, B. Pre-treatment methods for enhanced biogas production from sisal waste. In: AHRING, B.K. and HARTMANN, H. eds. Proceedings of the $4^{\text {th }}$ International Symposium on Anaerobic Digestion of Solid Waste $\left(31^{\text {st }}\right.$ August $-2^{\text {nd }}$ September, Copenhagen, Denmark). 2005, vol. 1, p. 116123.

DI FRANCO, C.R.; CYRAS, V.P.; BUSALMEN, J.P.; RUSECKAITE, R.A. and VAZQUEZ, A. Degradation of polycaprolactone/starch blends and composites with sisal fibre. Polymer Degradation and Stability, October 2004, vol. 86, no. 1, p. 95-103.

GIKAS, Petros and LIVINGSTON, Andrew G. Investigation of biofilm growth and attrition in a threephase airlift bioreactor using ${ }^{35} \mathrm{SO}_{4}{ }^{2-}$ as a radiolabelled tracer. Journal of Chemical Technology and Biotechnology, June 2006, vol. 81, no. 6, p. 858-865.

GOERING, H.K. and VAN SOEST, P.J. Forage fibre analyses (Apparatus, Reagents, Procedures, and some Applications). Washington, DC, Agricultural Research Service-United States Department of Agriculture, Agricultural handbook no. 379, 1970. 20 p.

HARENDRANATH, C.S.; ANUJA, K.; SINGH, A.; GUNASEELAN, A.; SATISH, K. and LALA, K. Immobilization in fixed film reactors: an ultrastructural approach. Water Science and Technology, 1996, vol. 33, no. 8, p. 7-15.

HELD, Christof; WELLACHER, Martin; ROBRA, KarlHeinz and GÜBITZ, Georg M. Two stage anaerobic fermentation of organic waste in CSTR and UFAF-reactors. Bioresource Technology, January 2002, vol. 81, no. 1, p. 19-24.

INCE, O.; INCE, K.B. and DONNELLY, T. Attachment, strength and performance of a porous media in an upflow anaerobic filter treating dairy wastewater. Water Science and Technology, 2000, vol. 41, no. 4-5, p. 261-270.

LALOV, Ivo G.; KRYSTEVA, Milka A. and PHELOUZAT, Jean-Louis. Improvement of biogas production from vinasse via covalently immobilized methanogens. Bioresource Technology, August 2001, vol. 79, no. 1, p. 83-85.

LENS, Piet N.L.; O’FLAHERTY, Vincent; DIJKEMA, Cor; COLLERAN, Emer and STAMS, Alfons J.M. Propionate degradation by mesophilic anaerobic sludge: degradation pathways and effects of other volatile fatty acids. Journal of Fermentation and Bioengineering, 1996, vol. 82, no. 4, p. 387-391.

MÖSCHE, Marek and JÖRDENING, Hans-Joachim. Comparison of different models of substrate and product inhibition in anaerobic digestion. Water Research, August 1999, vol. 33, no. 11, p. 2545-2554.

MSHANDETE, Anthony; KIVAISI, Amelia; RUBINDAMAYUGI, Mugassa and MATTIASSON, Bo. Anaerobic batch co-digestion of sisal pulp and fish wastes. Bioresource Technology, October 2004, vol. 95, no. 1, p. 19-24.

MSHANDETE, Anthony; BJÖRNSSON, Lovisa; KIVAISI, Amelia K.; RUBINDAMAYUGI, Mugassa S.T. and MATTIASSON, Bo. Enhancement of anaerobic batch digestion of sisal pulp waste by mesophilic aerobic pretreatment. Water Research, April 2005, vol. 39, no. 8, p. 1569-1575.

MSHANDETE, Anthony; BJÖRNSSON, Lovisa; KIVAISI, Amelia K.; RUBINDAMAYUGI, Mugassa S.T. and MATTIASSON, Bo. Effect of particles size on biogas yield from sisal fibres waste. Renewable Energy, November 2006, vol. 31, no. 14, p. 2385-2392.

ØDEGAARD, H.; GISVOLD, B. and STRICKLAND, J. The influence of carrier size and shape in the moving bed biofilm process. Water Science and Technology, 2000, vol. 41, no. 4-5, p. 383-391.

PARAWIRA, Wilson; MURTO, Marika; READ, John S. and MATTIASSON, Bo. Volatile fatty acid production during anaerobic mesophilic digestion of solid potato waste. Journal of Chemical Technology and Biotechnology, July 2005, vol. 79, no. 7, p. 673-677.

PIND, Peter F.; ANGELIDAKI, Irini and AHRING, Birgitte K. Dynamics of the anaerobic process: effects of volatile fatty acids. Biotechnology and Bioengineering, 2002, vol.82, no. 7, p. 791-801.

PULLAMMANAPPALLIL, Pratap C.; CHYNOWETH, David P.; LYBERATORS, Gerasimos and SVORONOS, Spyros A. Stable performance of anaerobic digestion in the presence of high concentration of propionic acid. Bioresource Technology, June 2001, vol. 78, no. 2, p. 165169.

ROMERO-GONZALEZ, J.; PERALTA-VIDEA, J.R.; RODRIGUEZ, E.; DELGADO, $M$. and GARDEATORRESDEY, J.L. Potential of Agave lechuguilla biomass for $\mathrm{Cr}$ (III) removal from aqueous solutions: thermodynamic studies. Bioresource Technology, January 2006, vol. 97, no. 1, p. 178-182.

RUBINDAMAYUGI, M.S.T. and SALAKANA, L.K.P. Biogas production from UASB and polyurethane carrier reactors treating sisal processing wastewater. In: Proceedings: Biogas Bioenergy Seminar $\left(21^{\text {st }}-23^{\text {rd }}\right.$ September, Silver Sands, Dar es Salaam, Tanzania). 1997, p. 29-38. 
SUVAJITTANONT, W. and CHAIPRASERT, P. Potential of biogas recirculation to enhance biomass accumulation on supporting media. Bioresource Technology, June 2003, vol. 88, no. 2, p. 157-162.

WANG, Qun-Hui; KUNINOBU, Masaaki; OGAWA, Hiroaki I. and KATO, Yasuhiko. Degradation of volatile fatty acids in highly efficient anaerobic digestion. Biomass and Bioenergy, June 1999, vol. 16, no. 6, p. 407-416.

YANG, Yingnan; TSUKAHARA, Kenichiro; YAGISHITA, Tatsuo and SAWAYAMA, Shigeki. Performance of a fixed bed reactor packed with carbon felt during anaerobic of cellulose. Bioresource Technology, September 2004, vol. 94, no. 2, p. 197-201. 